\title{
Evaluation of land use impact on river water quality using macroinvertebrates as bioindicator in Lahumoko Watershed, Buton Island, Indonesia
}

\author{
KAHIRUN ${ }^{1, \vartheta}$, LAODE SABARUDDIN ${ }^{2}$, MUKHTAR ${ }^{3}$, LAODE MUHAMMAD HARJONI KILOWASID ${ }^{2}$ \\ ${ }^{1}$ Department of Environmental Science, Faculty of Forestry and Environmental Science, Universitas Halu Oleo. BTN UHO Kampus Baru Blok M. No. \\ 15, Kambu, Kendari City 93231, Southeast Sulawesi, Indonesia. "email: irkahirun@ gmail.com \\ ${ }^{2}$ Department of Agrotechnology, Faculty of Agriculture, Universitas Halu Oleo. Jl. HEA Mokodompit, Kendari City 93231, Southeast Sulawesi, \\ Indonesia \\ ${ }^{3}$ Department of Agribusiness, Faculty of Agriculture, Universitas Halu Oleo. Jl. HEA Mokodompit, Kendari City 93231, Southeast Sulawesi, Indonesia
}

Manuscript received: 16 January 2019. Revision accepted: 21 May 2019.

\begin{abstract}
Kahirun, Sabaruddin L, Mukhtar, Kilowasid LMH. 2019. Evaluation of land use impact on river water quality using macroinvertebrates as bioindicator in Lahumoko Watershed, Buton Island, Indonesia. Biodiversitas 20: 1658-1670. The Lahumoko Watershed, a small watershed, that empties into the sea is sensitive to water quality changes due to land use changes by humans. Uncontrolled land use changes can threaten the sustainability of the river ecological functions of the watershed. It is important to examine the comparison of river water quality in locations that represent land uses. So, the objectives of this study were to reveal the impact of land use on biological water quality in rivers and to analyze the relationship between macroinvertebrates communities with parameters of biodiversity and physicochemical at the observation locations that represented land use. Biological samplings were done using a hand net with a hole size of $0.5 \mathrm{~mm}$ mesh, at five stations, each with three replications, with a length of $30 \mathrm{~m}$ of each replication, 60 minutes per station. The results of the study showed that individual abundance, family biotic index and diversity index parameters indicated that the water quality was quite good in the upstream watershed (LM1, LM2, and LM3 stations) and somewhat worse in the middle (LM4 station) and downstream of the watershed (LM5 station). The Spearman's correlation, Dendrogram, and Canonical Correspondent Analysis (CCA) showed that there were similarities among LM1, LM2 and LM3 stations, and also between LM4 and LM5 stations. Physicochemical parameters, especially the velocity and flow rate of the river flow had significant correlation with individual richness and density.
\end{abstract}

Keywords: Biodiversity, landuse, physicochemical parameters, water quality, watershed

\section{INTRODUCTION}

Ecosystem services of a watershed in the forms of water supply, water risk mitigation, and cultural benefits play a vital role in the sustainability of human welfare (Hamel et al. 2017). Uncontrolled land use changes in the watershed adversely affect the sustainability of watershed functions in the tropics, both large and small watersheds in small islands (Zhang et al. 2013; Shafie et al. 2017). A watershed is often used as a unit to evaluate the impact of land use changes on river water quality (Chen and Lu 2014; Flotemersch et al. 2016; Cheng et al. 2018). Small size watersheds have an area of not more than 10,000 hectares (Uhlenbrook et al. 2004). Changes of forest land to agricultural areas, settlements, and infrastructure are associated with a decrease in the quality of river water flowing in a watershed (Mophin-Kani K and Murugesan 2014; Pullanikkatil et al. 2015; Kim et al. 2016; Jonsson et al. 2017).

In Buton Island, Southeast Sulawesi Province, there is a small watershed, i.e., Lahumuko watershed. Currently, there are three land use types in the Lahumoko Watershed, namely forest, farmland, and settlements. The land use of forest dominates the upstream part of the watershed, while the agricultural land use is in the middle part, and residential land use interspersed with agricultural use is located in the downstream. Since North Buton District was declared a new autonomous region on January 2, 2007, forest land in the Lahumoko Watershed had been converted into a mixed plantation area, seasonal crop fields and rural settlements with the rate of change of $0.84 \%$ per year in the period from 2007 to 2017 (Land Use Map of North Buton, pers. obs.). The reduction in forest cover area is always followed by an increase in the surface flow rate, the transport of soil particles, organic material, and nutrient to enter the river water bodies in the rainy season (Silva et al. 2012; Hepp et al. 2013). Agricultural activities in the form of dryland farming with rice and secondary crops and the use of fertilizers and pesticides are the source of river water pollution (Andrade et al. 2011; Silva et al. 2012; Mori et al. 2015).

Land use changes affect the physicochemical characteristics of water that determine the quantity and quality of river water. Water quantity is measured by runoff parameters through discharge, and velocity (Khatri and Tyagi 2015; Tesfaye et al. 2017). Likewise, other human activities can also alter other physical-chemical variables such as pH, DO, Conductivity, and TDS (Niyogi et al. 2004; Silva et al. 2012; Zhang et al. 2013).

Subsequently, macroinvertebrates provide an ecological response to the river's new environmental conditions in the 
form of changes in composition, abundance, and diversity (Lewin et al. 2015). Macroinvertebrates play a key role in regulating carbon, nutrient deposition and decomposition of organic matter in river ecosystems (Pinna et al. 2003; Fonnesu et al. 2004; Sangiorgio et al. 2004; Minshall et al. 2014). To date, macroinvertebrates frequently receive particular attention in the evaluation of the impact of land use changes on the quality and health of river ecosystems (Ojija and Laizer 2016; Thampy et al. 2013). The use of macroinvertebrates for bioindicators of changes in river water quality is related to its biological characteristics, namely limited mobility, long life period. A number of taxa are very sensitive and certain taxa are highly sensitive and tolerant to changes in water discharge, flow velocity, $\mathrm{pH}$, DO, organic matter content, other pollutant loads and drought events (Di Sabatino et al. 2014; Pinna et al. 2016; Dacayana et al. 2013; Heino et al. 2014; Patrick et al. 2015). Most studies related to the impact of land use change on river macroinvertebrates communities were carried out in rivers on the continent, but few such investigations have been reported for rivers in small offshore islands (Bass 2003; Niyogi et al. 2004; Pullanikkatil et al. 2015; Shafie et al. 2017).

Changes in the diversity of aquatic macroinvertebrates (Hepp et al. 2013; Shafie et al. 2017) and abundance (Gimenez et al. 2015; Ojija and Kavishe 2016) have been studied to monitor river water quality due to the increased intensity of land use change. Ecologists have used various biological indices in different countries. The most commonly used indices in biological evaluation of rivers include species richness, evenness, diversity, dominance, and biotic indices (Yazdian et al. 2014). Thus, the purposes of this study were: (i) studying the impact of land use on the ecological indicators of water quality from the Lahumoko River, and (ii) analyzing the correlation between the parameters of macroinvertebrates communities and physicochemical parameters of river water quality and the differences among land uses.

\section{MATERIALS AND METHODS}

\section{Characteristics of study site}

This research was carried out along the Lahumoko River located at $04^{0} 57^{\prime} 57^{\prime \prime}-04^{0} 59^{\prime} 05^{\prime \prime} \mathrm{S}$ latitude and $122^{0}$ $52^{\prime} 40$ "- $122^{0} \quad 56^{\prime} \quad 47^{\prime \prime}$ E longitude. The Lahumoko Watershed is a small watershed in Buton Island, Southeast Sulawesi, Indonesia, an offshore island with an area of about 560,000 hectares having many small watersheds (Patterson et al. 2017). The Lahumoko Watershed occupies around 5,190.35 hectares of a total of 193,000 hectares of North Buton District and is located in the northern part of Buton Island (Land Use Map of North Buton, pers. obs.).

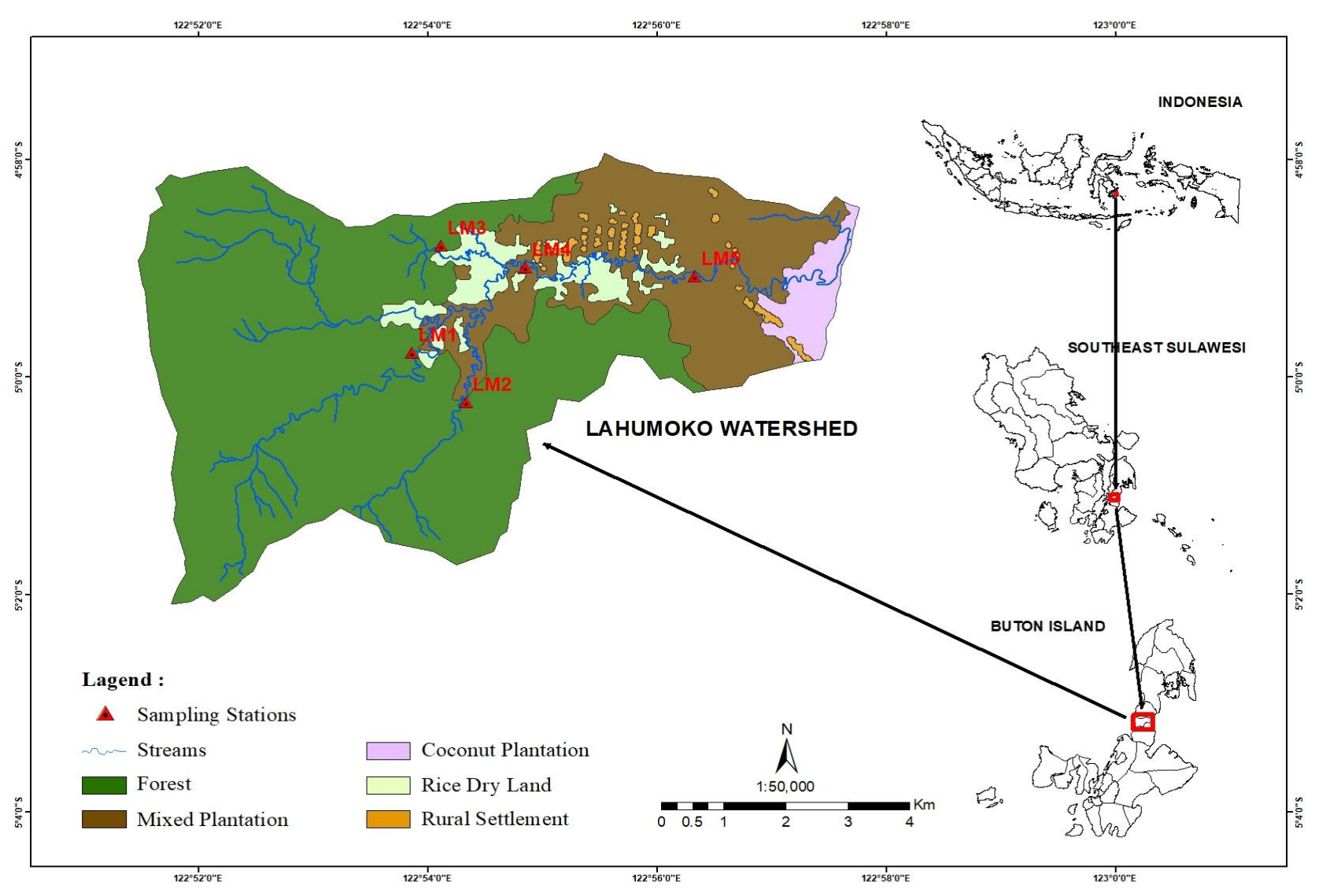

Figure 1. Map of the study area in Lahumoko Watershed, North Buton (Buton Island), Southeast Sulawesi, Indonesia 
Table 1. Description of sampling stations

\begin{tabular}{|c|c|c|}
\hline $\begin{array}{l}\text { Sampling } \\
\text { station } \\
\text { codes } \\
\end{array}$ & Geographic stations & Land use \\
\hline LM1 & $04^{0} 59^{\prime} 46^{\prime \prime} \mathrm{S}$ and $122^{0} 53^{\prime} 51^{\prime \prime} \mathrm{E}$ & $\begin{array}{l}\text { The station that covers the sub-watersheds with land use dominated by } 97.60 \% \\
\text { forests area and the rest }(2.40 \%) \text { is agriculture land area. }\end{array}$ \\
\hline LM2 & $04^{0} 59^{\prime} 29^{\prime \prime} \mathrm{S}$ and $122^{0} 54^{\prime} 25^{\prime \prime} \mathrm{E}$ & $\begin{array}{l}\text { The station that covers the sub-watersheds with land use dominated by } 81.01 \% \\
\text { forests area and the rest }(18.98 \%) \text { is agriculture land area. }\end{array}$ \\
\hline LM3 & $04^{0} 58^{\prime} 37^{\prime \prime} \mathrm{S}$ and $122^{0} 54^{\prime} 10^{\prime \prime} \mathrm{E}$ & $\begin{array}{l}\text { The station that covers the sub-watersheds with land use dominated by } 80.09 \% \\
\text { forests area and the rest }(19.91 \%) \text { is agriculture land area. }\end{array}$ \\
\hline LM4 & $04^{0} 59^{\prime} 02^{\prime \prime} \mathrm{S}$ and $122^{0} 54^{\prime} 40^{\prime \prime} \mathrm{E}$ & $\begin{array}{l}\text { The station that covers the middle part of the Lahumoko Watershed with mixed land } \\
\text { use types, consisting of agriculture plantation, forest plantation, and annual } \\
\text { cultivation. }\end{array}$ \\
\hline LM5 & $04^{0} 59^{\prime} 15^{\prime \prime} \mathrm{S}$ and $122^{0} 56^{\prime} 34^{\prime \prime} \mathrm{E}$ & $\begin{array}{l}\text { The station that covers the downstream part of the Lahumoko Watershed with } \\
\text { settlement land use interspersed with mixed plantations. }\end{array}$ \\
\hline
\end{tabular}

Lahumoko Watershed has the highest altitude of around 800 meters above sea level (Martin et al. 2017). Climatic conditions are characterized by an average rainfall of 1,751 $\mathrm{mm}$ year $^{-1}$ and an average air temperature of $27.5^{\circ} \mathrm{C}$. The rainy season lasts from November to June and the dry season lasts from July to September, and the highest rainfall occurs between April and June (Whitten et al. 2002; Patterson et al. 2017). The topography of the Lahumoko Watershed is generally hilly and slightly flat. Geomorphologically, the Lahumoko Watershed is dominated by the shape of a steep hill above marl with limestone outcrops covering $61 \%$, and the rest consists of hills with an asymmetric non-oriented sedimentary ridge covering $28 \%$, intertidal mud plains in under halophyte covering 6\%, and sloping non-volcanic alluvial fan covering 5\%. Geologically, it is dominated by Tmtc (Tondo Formation) rocks, covering approximately 78\%, alluvium 16\%, and swamps and beaches 6\% (Smith and Silver 1991; Sikumbang et al. 1995). The type of soil in the Lahumoko Watershed is dominated by Cambisol soil with an area of $66 \%$, and the rest is podsolic soil, $28 \%$ and Gleisol soil, 6\%, spread around rivers and beaches. (Map Land Type of North Buton Regency, Not Published). Limestone rocks produce calcareous soils, that are frequently thin and free draining, although sometimes they contain considerable amounts of clay and organic components known as Cambisol soil types. Sandstones and conglomerates produce acid soils which are generally poor in nutrients known as podzolic. The river valleys and coastal areas contain alluvial deposits which can vary greatly in composition, depending on the sediment washed away by the river flow, known as Gleisol soil (Powling et al. 2015).

\section{Sampling location}

Sampling was done to represent the upstream use of watershed with forest land use, the central part of the watershed used as an area of agriculture and mixed gardens, and downstream used as plantations and settlements. In the upper watershed area, there were three observation stations (LM1, LM2, and LM3) located in the third river tributaries branching, one station (LM4) in the middle stream, and one station (LM5) in the downstream (Table 1).

\section{Sample collection}

Aquatic macroinvertebrates were sampled using aquatic D-hand net with a dimension of $900 \mathrm{~cm}$ frame, $250 \mu \mathrm{m}$ mesh, $50 \mathrm{~cm}$ length. At each sampling station, the aquatic insects were sampled in rivers influenced by forest area (no or little anthropogenic disturbances), agricultural area, and rural settlement area. Each sampling site covered approximately $100 \mathrm{~m}$-long river water. Three replicates of each of the six important habitats (run, riffle, pool, leaf litter, aquatic vegetation and stone substrate) were collected at each station, considering all possible microhabitats over representative sections of the stream. The sampling time at each habitat was 3 minutes. All aquatic insects were sorted and preserved in $80 \%$ ethanol. The aquatic insects were identified to the family level with a guidebook.

Physicochemical parameters measurements were done at the same time as the collection of samples of aquatic insects. At each sampling station, physicochemical parameters i.e. Dissolved Oxygen (DO), Conductivity, pH, Total Dissolved Sediment (TDS), water temperature, velocity, and river flow were measured with three replications. Dissolved oxygen (DO) was measured directly in the field using portable oxygen tester in water (DO8401). Conductivity, $\mathrm{pH}$, and TDS were measured directly using portable high precision conductivity meters (AZ8306). Flow velocity and river flow were measured directly in the field using a Flow Meter type instrument Global Water FP 111 Current Meter.

\section{Statistical analyses}

The parameters of macroinvertebrates community were analyzed, namely the number of the families, family diversity index, and Family Biotic Index (FBI). The family diversity index stated in Shannon's diversity index, maximum diversity index $\left(\mathrm{H}_{\max }\right)$, Pielou evenness index, and Margalef richness index (Magurran 2004; Zaiha et al. 2015). The Shannon-Wienner Index was calculated using the formula: $H^{\prime}=-\sum_{i=1}^{n}\left(\frac{n i}{n}\right) \ln \left(\frac{n i}{n}\right)$ in which $\mathrm{H}^{\prime}$ is Shannon 
index, ni is the number of individuals of family $\mathrm{i}$, and $\mathrm{N}$ is number of all individuals (Shannon 1948). The value of $\mathrm{H}_{\max }$ was calculated using the formula: $\mathrm{H}_{\max }=\sum_{\mathrm{i}=1}^{s}\left(\frac{1}{s}\right) \log \left(\frac{1}{s}\right)=\log s$ in which $\mathrm{s}$ is the number of families. Pielou evenness index was calculated using the formula: $J=H^{\prime} / H_{\max }$ (Troussellier and Legendre 1981). Margalef richness index was calculated using the formula: $D_{M g}=\frac{\mathrm{s}-1}{\ln (\mathrm{n})}$ in which $\mathrm{s}$ is the number of families and $\mathrm{n}$ is the number of individuals (Legendre and Legendre 1998). The Family Biotic Index was calculated using the formula developed by Hilsenhoff (1998): $\mathrm{FBI}=\sum_{i=1}^{i-n} \Gamma\left(\mathrm{TV}_{\mathrm{i}} / n_{i}\right) \mathrm{l} / \mathrm{N}$, in which FBI states the benthic macroinvertebrate index, $\mathrm{i}$ states the order of the families composing the macroinvertebrate community, ni states the number of the individual belonging to family $i$, TVi states the value of tolerance of the family $\mathrm{i}$, and $\mathrm{N}$ states the number of all individuals composing the macroinvertebrate community (Sharifinia et al. 2016).

Variant analysis (ANOVA), at p level of 0.05 was used to test the difference in density, diversity index, and the index of macroinvertebrate biotic among different land uses. If the difference was significant, then LSD test at 0.05 level was conducted. The exploration of the correlation between species and environmental variables was done using multivariate correlation using SPSS 23 and PAST (PAleontological STatistics) Version 3.23 software. Data of family density and environmental variables (except $\mathrm{pH}$ ) were transformed to $\log (\mathrm{x}+1)$. Spearman correlation analysis was conducted to determine correlation among the environmental variables. Only correlation of $r \geq 0.60$ ( $p$
$<0.05)$ was considered significant. Lastly, the cluster analysis and CCA (Canonical Correspondence Analysis) were conducted using PAST software.

\section{RESULTS AND DISCUSSION}

\section{Biodiversity of aquatic macroinvertebrate communities}

A total of 2869 individuals of aquatic macroinvertebrates were collected, distributed among 13 families and 8 orders. LM3 and LM4 had the highest taxa richness of macroinvertebrates (8 families and 7 orders, respectively) belonging to orders Trichoptera, Ephemeroptera, Gastropoda, Crustacea, Coleoptera, Odonata, Diptera, and Hemiptera. Meanwhile, LM5 had the lowest taxa ( 6 families and 4 orders) represented by orders Gastropoda, Crustacea, Trichoptera and Hemiptera. The total number of individuals recorded at LM3 was 1,492 individuals which were the highest, followed by that of LM1 with 712 individuals, while the least total number of individuals were recorded at LM4 and LM5 with 213 and 116 individuals respectively (Table 2).

At LM3, the highest number of individuals was found in the families Thiaridae, Atyidae, Parathelpusidae, Goeridae and Heptageniidae which were significantly different from the other stations followed by LM1 and LM 2. While at LM4 and LM5, the family mentioned above were added with the families Mesovellidae, Cordulidae, and Dytiscidae, but the number of individuals was the lowest.

Table 2. Mean population and difference of aquatic macroinvertebrates (means \pm sd, $n=3$ ) at each station along Lahumoko River, North Buton (Buton Island), Southeast Sulawesi, Indonesia

\begin{tabular}{|c|c|c|c|c|c|c|}
\hline \multirow{2}{*}{ Order and Family } & \multicolumn{5}{|c|}{ Observation stations } & \multirow{2}{*}{$\begin{array}{l}\text { LSD } \\
\text { 0.05) }\end{array} \quad(\mathbf{p}<$} \\
\hline & LM 1 & LM 2 & LM 3 & LM 4 & LM 5 & \\
\hline \multicolumn{7}{|l|}{ Order Gastropoda } \\
\hline Thiaridae & $330.30 \pm 5.25^{\mathrm{d}}$ & $122.38 \pm 5.58^{c}$ & $723.16 \pm 9.78^{e}$ & $98.89 \pm 1.92^{\mathrm{b}}$ & $25.54 \pm 4.31^{\mathrm{a}}$ & 4.76 \\
\hline Physidae & $0.00^{\mathrm{a}}$ & $0.00^{\mathrm{a}}$ & $0.00^{\mathrm{a}}$ & $0.00^{\mathrm{a}}$ & $11.73 \pm 2.39^{b}$ & 0.99 \\
\hline \multicolumn{7}{|l|}{ Order Crustacea } \\
\hline Atyidae & $142.42 \pm 10.50^{b}$ & $148.15 \pm 2.79^{c}$ & $299.43 \pm 9.78^{d}$ & $34.44 \pm 1.93^{\mathrm{a}}$ & $32.44 \pm 2.39^{\mathrm{a}}$ & 4.80 \\
\hline Parathelpusidae & $84.85 \pm 10.50^{\mathrm{b}}$ & $25.76 \pm 2.79^{a}$ & $209.04 \pm 25.89^{c}$ & $28.89 \pm 1.92^{\mathrm{a}}$ & $23.46 \pm 3.17^{\mathrm{a}}$ & 8.83 \\
\hline Agridae & $33.33 \pm 5.25^{\mathrm{b}}$ & $0.00^{\mathrm{a}}$ & $73.45 \pm 19.57^{c}$ & $0.00^{\mathrm{a}}$ & $0.00^{\mathrm{a}}$ & 3.17 \\
\hline Palemonidae & $0.00^{\mathrm{a}}$ & $0.00^{\mathrm{a}}$ & $0.00^{\mathrm{a}}$ & $4.45 \pm 3.85^{\mathrm{b}}$ & $0.00^{\mathrm{a}}$ & 0.60 \\
\hline \multicolumn{7}{|l|}{ OrderTrichoptera } \\
\hline Goeridae & $39.39 \pm 5.25^{\mathrm{d}}$ & $25.76 \pm 7.38^{c}$ & $96.04 \pm 9.78^{e}$ & $7.78 \pm 1.92^{\mathrm{b}}$ & $2.76 \pm 1.20^{\mathrm{a}}$ & 3.72 \\
\hline \multicolumn{7}{|l|}{ Order Ephemeroptera } \\
\hline Heptageniidae & $57.58 \pm 5.25^{\mathrm{c}}$ & $12.88 \pm 2.79^{b}$ & $56.50 \pm 9.79^{c}$ & $0.00^{\mathrm{a}}$ & $0.00^{\mathrm{a}}$ & 4.62 \\
\hline \multicolumn{7}{|l|}{ Order Hemiptera } \\
\hline Mesovellidae & $0.00^{\mathrm{a}}$ & $3.22 \pm 2.79^{\mathrm{b}}$ & $0.00^{\mathrm{a}}$ & $34.44 \pm 1.92^{\mathrm{d}}$ & $20.01 \pm 3.16^{\mathrm{c}}$ & 1.08 \\
\hline \multicolumn{7}{|l|}{ Order Odonata } \\
\hline Corduliidae & $24.24 \pm 5.25^{\mathrm{c}}$ & $0.00^{\mathrm{a}}$ & $0.00^{\mathrm{a}}$ & $2.22 \pm 3.85^{\mathrm{b}}$ & $0.00^{\mathrm{a}}$ & 2.70 \\
\hline Amphipterygidae & $0.00^{\mathrm{a}}$ & $0.00^{\mathrm{a}}$ & $11.3 \pm 9.78^{\mathrm{b}}$ & $0.00^{\mathrm{a}}$ & $0.00^{\mathrm{a}}$ & 1.53 \\
\hline \multicolumn{7}{|l|}{ Order Diptera } \\
\hline Tipulidae & $0.00^{\mathrm{a}}$ & $0.00^{\mathrm{a}}$ & $22.60 \pm 9.78^{b}$ & $0.00^{\mathrm{a}}$ & $0.00^{\mathrm{a}}$ & 4.05 \\
\hline \multicolumn{7}{|l|}{ Order Coleoptera } \\
\hline Dytiscidae & $0.00^{\mathrm{a}}$ & $0.00^{\mathrm{a}}$ & $0.00^{\mathrm{a}}$ & $2.22 \pm 3.85^{\mathrm{b}}$ & $0.00^{\mathrm{a}}$ & 1.60 \\
\hline
\end{tabular}

Note: Numbers followed by different letters in the same row show significant differences according to the LSD test at level 0.05 . 
Table 3. The physicochemical parameters (means $\pm s d, n=3$ ) at five observation stations in Lahumoko River, North Buton (Buton Island), Southeast Sulawesi, Indonesia

\begin{tabular}{|c|c|c|c|c|c|c|}
\hline \multirow[b]{2}{*}{ Parameters } & \multicolumn{5}{|c|}{ Observation stations } & \multirow{2}{*}{$\begin{array}{c}\text { LSD } \\
(\mathrm{p}< \\
0.05)\end{array}$} \\
\hline & Sta.LM1 & Sta.LM2 & Sta.LM3 & Sta.LM4 & Sta.LM5 & \\
\hline Velocity $\left(\mathrm{m} \mathrm{det}^{-1}\right)$ & $0.93 \pm 0.014^{\mathrm{b}}$ & $0.79 \pm 0.028^{b}$ & $0.50 \pm 0.071^{\mathrm{a}}$ & $1.30 \pm 0,212^{\mathrm{c}}$ & $1.48 \pm 0.240^{\mathrm{c}}$ & 0.22 \\
\hline Discharge $\left(\mathrm{m}^{3} \operatorname{det}^{-1}\right)$ & $1.09 \pm 0.042^{\mathrm{b}}$ & $1.81 \pm 0.071^{\mathrm{c}}$ & $0.36 \pm 0,057^{\mathrm{a}}$ & $4.76 \pm 0,078^{\mathrm{d}}$ & $7.13 \pm 0.028^{\mathrm{e}}$ & 0.09 \\
\hline Temperature $\left({ }^{\circ} \mathrm{C}\right)$ & $28.3 \pm 0.141^{\mathrm{ab}}$ & $28.00 \pm 0.212^{\mathrm{a}}$ & $28.40 \pm 0.283^{\mathrm{ab}}$ & $29.20 \pm 0.354^{\mathrm{c}}$ & $28.5 \pm 0.424^{b}$ & 0.45 \\
\hline $\mathrm{pH}$ & $7.88 \pm 0.021^{\mathrm{bc}}$ & $7.82 \pm 0.028^{\mathrm{a}}$ & $7.85 \pm 0.042^{\mathrm{ab}}$ & $7.91 \pm 0.035^{\mathrm{cd}}$ & $7.95 \pm 0.014^{\mathrm{d}}$ & 0.04 \\
\hline Dissolved oxygen $\left(\mathrm{mg} \mathrm{l}^{-1}\right)$ & $6.92 \pm 0.077^{\mathrm{e}}$ & $6.79 \pm 0.049^{\mathrm{d}}$ & $6,53 \pm 0,035^{\mathrm{c}}$ & $6.30 \pm 0.028^{\mathrm{b}}$ & $6.23 \pm 0.035^{\mathrm{a}}$ & 0.06 \\
\hline Total dissolved suspended $\left(\mathrm{mg} \mathrm{l}^{-1}\right)$ & $41.20 \pm 0.919^{c}$ & $36.50 \pm 0.778^{a}$ & $39.40 \pm 0.566^{\mathrm{b}}$ & $41.30 \pm 0.849^{c}$ & $45.20 \pm 1.061^{\mathrm{d}}$ & 1.26 \\
\hline Conductivity $\left.(\mu \mathrm{S} \mathrm{cm})^{-1}\right)$ & $722 \pm 3.536^{\mathrm{a}}$ & $730 \pm 1.414^{b}$ & $753 \pm 2.828^{c}$ & $787 \pm 4.243^{\mathrm{d}}$ & $796 \pm 2.121^{\mathrm{e}}$ & 4.46 \\
\hline
\end{tabular}

Note: Numbers followed by different letters in the same row show significant differences according to the LSD test at 0.05 level.

\section{Physico-chemical parameters of the river water quality}

The physicochemical parameters, i.e. velocity, discharge, pH level, temperature, DO, TDS and conductivity were significantly different among five sampling stations in Lahumoko River. Table 3 shows that the largest flow velocity and discharge were found at LM5, significantly different from that of the other stations except for LM4. The lowest flow velocity and discharge in the upstream watershed were found at LM3, significantly different from that of the other four stations. The next lowest flow velocity and discharge were found in LM 1 and LM 2 in which both differed significantly.

The water temperature at LM1, LM2, and LM3 was not different from each other, but significantly different from that at LM4. The lowest water temperature was at the LM2, but not significantly different from that at LM1, LM3, and LM5. The highest temperature was found at LM4, different from that at the other stations.

The highest concentration of dissolved oxygen (DO) was recorded at the LM1, followed by LM2 and LM3, while the lowest DO was found at LM5 and LM4. In contrast, total suspended solids (TSS) and conductivity were found in LM4 and LM5, which were higher than those in LM1, LM2, and LM3.

Furthermore, the similarity of individual abundance and the similarity of physicochemical variables at each location of observation stations could be analyzed by analyzing dendrogram clusters (Figures 2 and 3 ).

Figures 2 and 3 show the results of hierarchical cluster analysis showing the results of hierarchical cluster analysis at each observation location based on family density and physicochemical variables using a distance or similarity measure of the Bray-Curtis Similarity Index with the Single Linkage Algorithm method. LM1, LM2, and LM3 had a high similarity, both in family density and physicochemical variables, due to the similarity of land use in the three stations which are dominated by forest. LM4 and LM5 stations also had a similarity in both family density and physicochemical variables because of the similarity of land use in the two stations, where LM4, is a mixed plantation and a field, while land use at LM5 station is a rural settlement interspersed with mixed plantations.

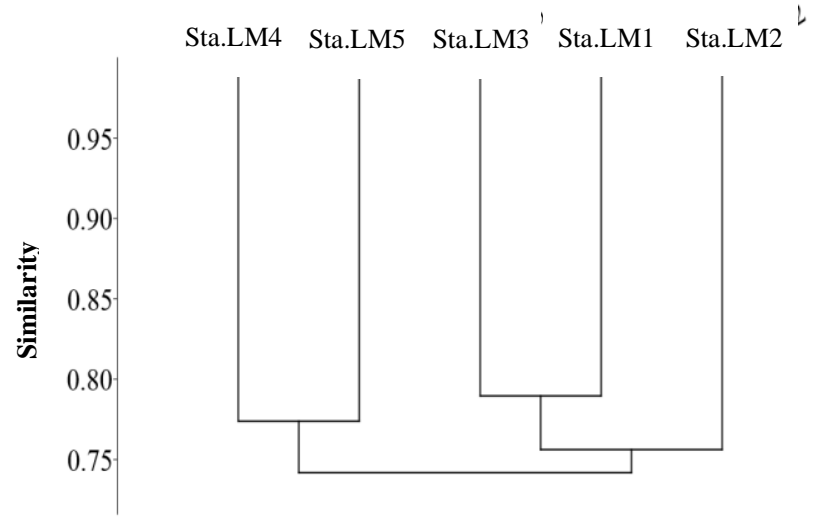

Figure 2. The results of hierarchical clustering analysis of location/station based on family density with the distance size of the Bray-Curtis Similarity Index and the Single Linkage Algorithm

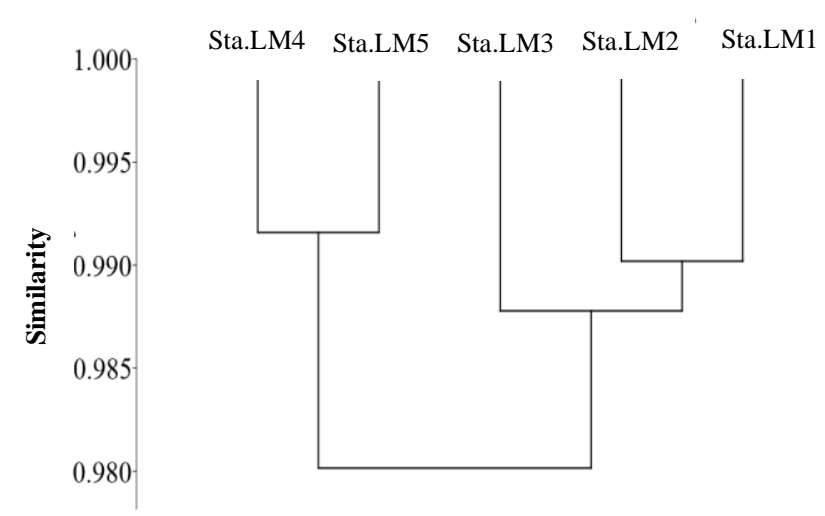

Figure 3. The results of hierarchical clustering analysis location/station based on physicochemical variables with the distance size of the Bray-Curtis Similarity Index and the Single Linkage Algorithm. 
Table 4. Differences in ecological indicators of water quality (means \pm SD, $n=3$ ) among five stations in Lahumoko river in Lahumoko Watershed, North Buton (Buton Island), Southeast Sulawesi, Indonesia

\begin{tabular}{|c|c|c|c|c|c|c|}
\hline \multirow[b]{2}{*}{ Indicator } & \multicolumn{5}{|c|}{ Observation stations } & \multirow{2}{*}{$\begin{array}{r}\text { LSD } \\
(p< \\
\mathbf{0 . 0 5})\end{array}$} \\
\hline & LM1 & LM2 & LM3 & LM4 & LM5 & \\
\hline Total of individual density (Ind. $\mathrm{m}^{-2}$ ) & $712.11 \pm 37.85^{\mathrm{d}}$ & $338.16 \pm 22.14^{\mathrm{c}}$ & $1491.53 \pm 84.74^{\mathrm{e}}$ & $213.34 \pm 18.57^{\mathrm{b}}$ & $115.94 \pm 15.63^{\mathrm{a}}$ & 40.67 \\
\hline Fami & $5.40 \pm 0.21^{\mathrm{ab}}$ & $5.16 \pm 0.17^{\mathrm{a}}$ & $5.61 \pm 0.19^{\mathrm{bc}}$ & $5.78 \pm 0.14^{\mathrm{cd}}$ & $6.07 \pm 0.34^{\mathrm{d}}$ & 0.33 \\
\hline $\operatorname{dex}\left(\mathrm{H}^{\prime}\right)$ & $1.55 \pm 0.03^{\mathrm{bc}}$ & $1.27 \pm 0.07^{\mathrm{a}}$ & $1.49 \pm 0.08^{\mathrm{b}}$ & $1.47 \pm 0.16^{\mathrm{b}}$ & $1.63 \pm 0.02^{\mathrm{c}}$ & 0.09 \\
\hline Maximum diversity index ( $\left.\mathrm{H}_{\max }^{\prime}\right)$ & $1.89 \pm 0.09^{\mathrm{bc}}$ & $1.73 \pm 0.11^{\mathrm{a}}$ & $2.04 \pm 0.08^{\mathrm{c}}$ & $1.82 \pm 0.24^{\mathrm{ab}}$ & $1.73 \pm 0.11^{\mathrm{a}}$ & 0.14 \\
\hline Pielou evenness index $\left(J^{\prime}\right)=H^{\prime} / H_{\text {max }}^{\prime}$ & $0.82 \pm 0.04^{b}$ & $0.73 \pm 0.02^{\mathrm{a}}$ & $0.73 \pm 0.02^{a}$ & $0.81 \pm 0.02^{b}$ & $0.94 \pm 0.05^{\mathrm{c}}$ & 0.03 \\
\hline Margalef richness index ( $\left.\mathrm{D}^{\prime} \mathrm{mg}\right)$ & $1.38 \pm 0.02^{\mathrm{c}}$ & $0.94 \pm 0.02^{\mathrm{a}}$ & $1.49 \pm 0.11^{\mathrm{d}}$ & $1.12 \pm 0.12^{\mathrm{b}}$ & $1.16 \pm 0.14^{b}$ & 0.11 \\
\hline
\end{tabular}

Note: Numbers in the same row followed by different letters show significant differences according to the LSD test at level of 0.05 .

\section{Measurement of ecological indicators of river water quality}

The total individual density, family biotic index, Shannon's diversity index, maximum diversity index, Pielou evenness index, and Margalef richness index varied among observation stations (Table 4). The total individual density was found at LM3, followed by LM1 and LM2.

LM5 had the highest value of the Family Biotic Index, significantly different from that at LM1, LM 2, and LM3, but was not significantly different from that of LM4. The lowest FBI value was found at LM2, significantly different from that at LM3, LM4, and LM5, but not significantly different from that at LM1.

Shannon's diversity index at LM5 was the highest, significantly different from that at LM2, LM3, and LM 4, but not significantly different from that at LM1. At LM2 the diversity index was the lowest and significantly different that of the other four stations. Maximum diversity index at LM3 was the highest, but not significantly different from that at LM1, while at LM2 and LM5 were the lowest, but not significantly different from that at LM4.

Pielou evenness index at LM5 was the highest, significantly different from that of the other four stations, while at both LM2 and LM3 were the lowest, which were also significantly different from those of the other three stations. The evenness Index provides a picture of the equality or similarity of species in the community.

The highest Margalef richness index was found at LM3, significantly different that of the other four stations, while the lowest was at LM2, which was significantly different from that of the other four stations. Meanwhile, the Margalef richness index at LM4 was not significantly different from that at LM5, but significantly different from that at LM1.

\section{Correlation between physicochemical parameters and ecological indicators of water quality based on macroinvertebrates}

Spearman's bivariate correlation analysis showed that the abundance of several macroinvertebrates families and the ecological measure of water quality were significantly correlated with a number of physicochemical parameters from the Lahumoko river's water (Table 5). The ecological parameters of water quality which include total abundance, the FBI index, and J'Evenness were significantly correlated with some physicochemical parameters, while others were not significant. Heptageniides with DO were correlated significantly positively $(\mathrm{p}=0.005)$, whereas the conductivity was correlated significantly negatively $(\mathrm{p}=$ 0.029). Goeridae with streamflow velocity, streamflow discharge $(\mathrm{p}=0.037)$, and $\mathrm{pH}(\mathrm{p}=0.037)$ were correlated significantly negatively $(\mathrm{p}=0.000)$. Similarly, Mesovellidae was correlated significantly positively with streamflow discharge $(p=0.014)$, while Thiaridae was correlated significantly negatively with streamflow discharge $(\mathrm{p}=$ 0.037). Meanwhile, Atyidae was correlated significantly negatively $(p=0.028)$ with temperature. The total abundance of river macroinvertebrates was correlated significantly negatively with streamflow velocity $(p=0.037)$ and streamflow discharge $(\mathrm{p}=0.00)$. Significantly positive correlation was also shown between FBI index with $\mathrm{pH}(\mathrm{p}$ $=0.037)$ and conductivity $(\mathrm{p}=0.014)$. Furthermore, the correlation between J'Eveness with velocity $(p=0.014)$, $\mathrm{pH}(\mathrm{p}=0.014)$ and TDS $(\mathrm{p}=0.005)$ was significant.

Correlations among dominant families, environmental parameters, diversity measures, and locations were identified using the CCA triplot analysis as in Figure 4. The first axis has an Eigenvalue of 0.086 (variance 54.06 $\%$ ), showing positive association among dominant families namely Heptageniidae, Goeridae, Atyidae, Agridae, Thiaridae, Amphipterygidae, Cordullidae, and Tipulidae; physicochemical parameters, namely DO; Biodiversity parameters were the total individuals, H'Max, and R'Margalef at locations LM1, LM2, and LM3 stations. Whereas negative association occurred among the dominant families, namely Parathepusidae, Palemonidae, Physidae, Mesovellidae, and Dytiscidae; with physicochemical parameters, namely Velocity, Discharge, pH, Temperature, TDS, and Conductivity; and biodiversity parameters, namely FBI, H 'Shannon and J'Evenness at LM4 and LM5.

The second axis has an Eigenvalue of 0.038 (variance $23.74 \%$ ) showing positive association among dominant families, namely Heptageniidae, Agridae, Atyidae, Amphipterygidae, Tipulidae, Parathepusidae, and Physidae; with physicochemical parameters, namely Temperature, pH, TDS, Conductivity, and DO; and Biodiversity parameters, namely FBI, H' Max, J 'Evenness and $\mathrm{H}$ 'Shannon at LM2, LM3 and LM5. Whereas negative association occurred among the dominant families, namely Goeridae, Palemonidae, Cordullidae, Mesovellidae, and Dytiscidae; physicochemical parameters, namely Discharge and Velocity; and Biodiversity parameters, namely total individuals and D' Margalef at LM1 and LM4. 
Table 5. Spearman's correlation between physicochemical condition, and ecological indicators of water quality based on macroinvertebrates communities in Lahumoko's river at Lahumoko Watershed, North Buton, Southeast Sulawesi, Indonesia

\begin{tabular}{|c|c|c|c|c|c|c|c|}
\hline \multirow{2}{*}{ Ecological indicator } & \multicolumn{7}{|c|}{ Physicochemical indicator } \\
\hline & Velocity & Discharge & Temp. & pH & DO & TDS & Conductivity \\
\hline \multicolumn{8}{|l|}{ Family abundance } \\
\hline Heptageniidae & -0.632 & -0.791 & -0.471 & -0.632 & $0.973^{* *}$ & -0.460 & $-0.917^{*}$ \\
\hline Goeridae & $-1.000^{* *}$ & $-0.900^{*}$ & -0.447 & $-0.900^{*}$ & 0.564 & -0.872 & -0.632 \\
\hline Atyidae & -0.718 & -0.462 & $-0.918^{*}$ & -0.821 & 0.500 & -0.763 & -0.649 \\
\hline Parathepulsidae & -0.051 & -0.205 & 0.344 & 0.359 & -0.395 & 0.368 & 0.487 \\
\hline Agridae & -0.577 & -0.866 & 0.000 & -0.289 & 0.592 & -0.148 & -0.456 \\
\hline Palemonidae & 0.354 & 0.354 & 0.791 & 0.354 & -0.544 & 0.181 & 0.559 \\
\hline Thiaridae & -0.700 & $-0.900^{*}$ & 0.224 & -0.400 & 0.410 & -0.359 & -0.316 \\
\hline Physidae & 0.707 & 0.707 & 0.000 & 0.707 & -0.544 & 0.725 & 0.559 \\
\hline Amphipterygidae & -0.707 & -0.707 & 0.000 & -0.354 & 0.000 & -0.363 & 0.000 \\
\hline Cordullidae & 0.224 & -0.112 & 0.500 & 0.224 & 0.344 & 0.287 & -0.177 \\
\hline Mesovellidae & 0.791 & $0.949^{*}$ & 0.354 & 0.632 & -0.811 & 0.487 & 0.750 \\
\hline Tipulidae & -0.707 & -0.707 & 0.000 & -0.354 & 0.000 & -0.363 & 0.000 \\
\hline Dytiscidae & 0.354 & 0.354 & 0.791 & 0.354 & -0.544 & 0.181 & 0.559 \\
\hline \multicolumn{8}{|c|}{ Measurement of ecological indicators of river water quality } \\
\hline Total of individual & $-0.900^{*}$ & $-1.000^{* *}$ & -0.224 & -0.700 & 0.667 & -0.616 & -0.632 \\
\hline Total of density & $-0.900^{*}$ & $-1.000^{* * *}$ & -0.224 & -0.700 & 0.667 & -0.616 & -0.632 \\
\hline Family Biotic Index (FBI) & 0.700 & 0.600 & 0.671 & $0.900^{*}$ & -0.872 & 0.821 & $0.949^{*}$ \\
\hline Shannon's diversity index (H') & 0.500 & 0.200 & 0.224 & 0.700 & -0.154 & 0.821 & 0.316 \\
\hline Maximum diversity index $\left(\mathrm{H}_{\max }^{\prime}\right)$ & -0.564 & -0.821 & -0.344 & 0.205 & 0.289 & -0.158 & -0.162 \\
\hline Pielou evenness index $\left(J^{\prime}\right)=H^{\prime} / H_{\max }^{\prime}$ & $0.949^{*}$ & 0.738 & 0.471 & $0.949^{*}$ & -0.460 & $0.973^{* *}$ & 0.583 \\
\hline Margalef richness index ( $\mathrm{D}_{\mathrm{mg}}^{\prime}$ ) & -0.400 & -0.700 & 0.447 & 0.000 & 0.154 & 0.051 & 0.000 \\
\hline
\end{tabular}

Note: * states a significant correlation at $\mathrm{p}$ of 0.05 level; ** states significant correlation at $\mathrm{p}$ of 0.01 level

\section{Discussion}

Biodiversity of aquatic macroinvertebrates communities

The results of the study indicated that land use had a significant impact on water quality in the watershed. Forested areas had better water quality than both agricultural land use and rural settlements as shown in Figure 4, due to the low anthropogenic input on forested land. Human disturbances to the forest land use are prime factors controlling macroinvertebrates communities in the river water (Gimenez et al. 2015; Santhosh et al. 2014). Species richness refers to the number of species present in an area determined by the island area and watershed in each region (Bass 2003; Shafie et al. 2017). The pollution due to land use activities influences the ecological quality of river waters (Selvanayagam and Abril 2016). LM1, LM2, and LM3, located in the tributary upper river, is dominated by forest land use which has little disturbance, so they had abundant macroinvertebrates, a bioindicator of undisturbed areas (Azmi and Geok 2016; Kim et al. 2016; dos Reis et al. 2017). The Lahumoko's upstream watershed area is represented by LM1, LM2, and LM3, showing that Ephemeroptera Order's Heptageniidae family and Trichoptera Order's Goeridae family had been found. This group of organisms belongs to the EPT group, very sensitive to pollution, so if these macroinvertebrates are found in the water, the water could be considered unpolluted, so the water quality of those three stations was considered slightly polluted (Young et al. 2014; Lewin et al. 2015). According to River Continuum Concept, the upstream is dominated by scrapper and shredder (Vannote et al. 1980). Shedders, predators, and scrapper species characterize the group of upstream biota at rough substrate upstream which is characterized by high elevation or mountains. Many scrapper species are present at the land used for agriculture and settlements with high pollution which is related to the increased water volume and river width and substrate dominated Mud and Clay's (Rosenberg and Resh 1993; Fu et al. 2016). Some shredder groups such as Ephemeroptera, Plecoptera, and Trichoptera on mountains and upstream area are sensitive to organic pollution and may serve as a river water bioindicator of unpolluted forest (Elias et al. 2014; Kim et al. 2016). The highest abundance is found in the upstream watershed and the lowest in the downstream which is characterized by flow velocities (SzczerkowskaMajchrzak and Grzybkowska 2015) and place heights according to river order, food and other environmental parameters (Jiang et al. 2011; Fu et al. 2016). The Coleoptera family is generally associated with calm and lentic water conditions and the Odonata family is mostly associated with moderate water pollution (Olomukoro and Dirisu 2014). 


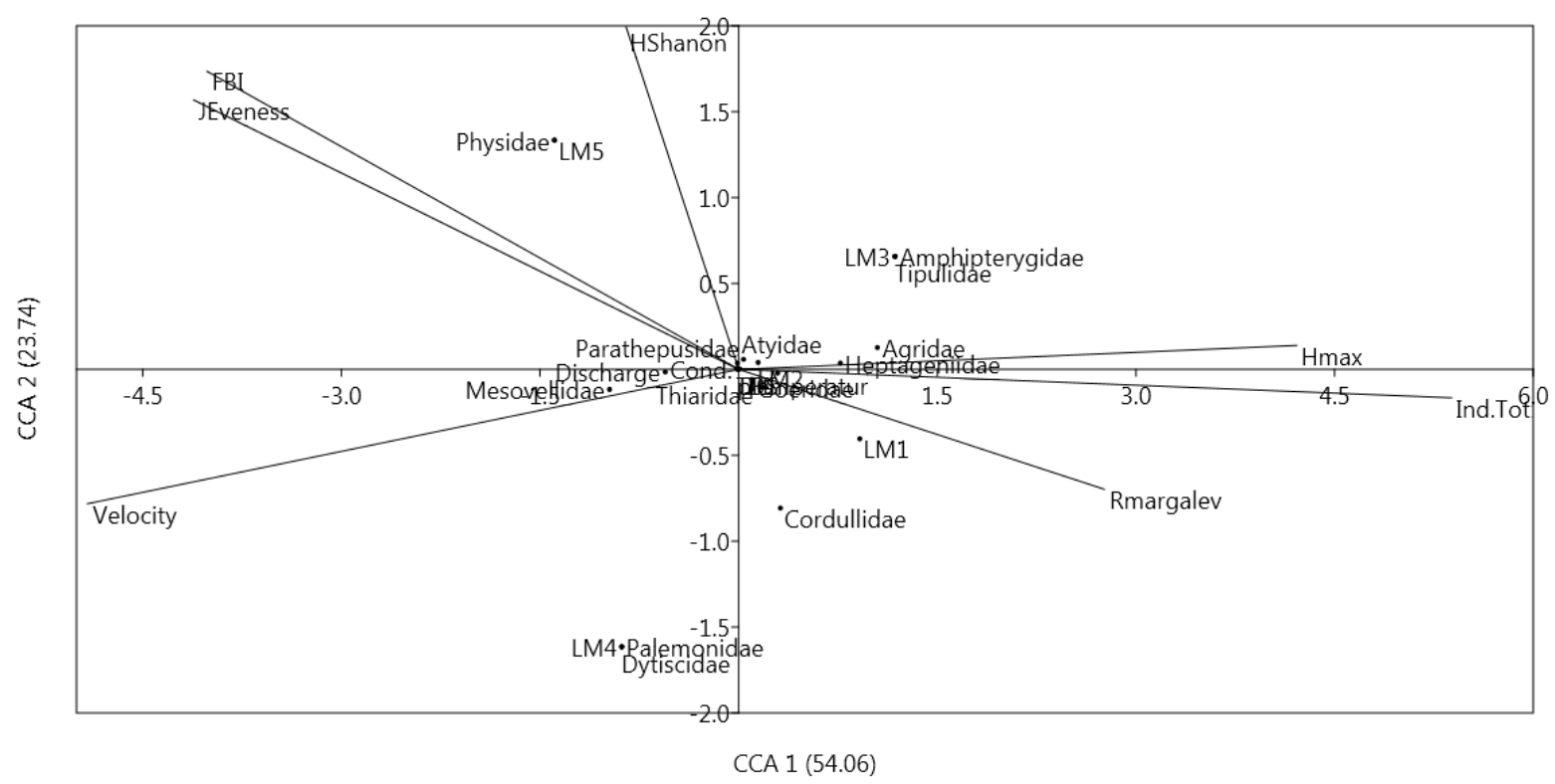

Figure 4. Results triplot CCA analysis showing an association among the dominant families, physicochemical parameters, ecological water quality indicators, and observation stations

Meanwhile, in LM4 and LM5 in the middle and downstream areas of the Lahumoko Watershed, humandisturbed areas, macroinvertebrate families found were Thiaridae and Phisidae of the Order Gastropods and family Atydae and Parathepusidae of the Order Crustacean which has larger number than other families (Edward et al. 2015). Both stations are agricultural areas and rural settlements. At LM 4 and LM 5, the family Goeridae of Trichoptera Order was found in a small number, indicating that the two stations were categorized as having moderately polluted water quality (Bouchard 2004; Copatti et al. 2013). This showed that this area was dominated by scrapper groups, both insects and non-insects of EPT in small number which could function as indicators for agricultural areas and settlements and the water was contaminated with organic contamination. The influence of the strength of the river flows in the middle and downstream areas causes a drastic reduction in the EPT group (Harikumar et al. 2014; Wang et al. 2016). The strength of river flow on the agricultural areas of the watershed which indicated by the decreased vegetation in the banks of the river has a strong influence on the presence of macroinvertebrates as an indicator of degradation of land use (Masese et al. 2014; Gerth et al. 2017). In the middle area of the Lahumoko Watershed, many agricultural activities could cause high soil erosion and riverbank erosion, in addition to other human activities such as bathing, and washing in the river causing changes in the physicochemical parameters of river water thus affecting macroinvertebrates abundance and water quality (Ojija and Laizer 2016). The use of nitrate fertilizer, phosphate, and pesticides on agricultural land has the effect of pollution on river water (Kripa et al. 2013). The pressure of human disturbance on land use can explain macroinvertebrates variability, especially the type of EPT, a finding that needs to be studied further, especially with regard to the intensity and scale of human disturbance (Ligeiro et al. 2013; Hepp et al. 2013).

\section{Physicochemical parameters of the river water quality}

The physicochemical characteristics in Lahumoko Watershed varied across different land use types. The relatively high variation of water quality parameters related to various types of land use are characteristics that can be used to inform or predict aspects of water quality in rivers that lack data. In this study, physicochemical parameters were significantly different among the stations as the measure in observing water quality that was related to the presence of macroinvertebrates (Mophin-Kani K and Murugesan 2014; Fierro et al. 2015; Shokri et al. 2014). Water temperature in the upstream of the watershed was low due to the closure of the water body by the forest compared to the middle and downstream part which was already opened, especially at the edge of the river (Rezende et al. 2016). Water temperature greatly influences organisms in the river and is inversely proportional to DO and Conductivity (Brooks et al. 2013; Gimenez et al. 2015; Patrick et al. 2015). This is shown in this study that TDS and Conductivity increased towards the downstream, accompanied by a decrease in DO (Shafie et al. 2017; Pina et al. 2016; Sharifinia et al. 2016). Low pH, high EC, low dissolved oxygen (DO), and high BOD were recorded, which characterize the degradation of water quality (Saviour 2012; Aazami et al. 2015). The $\mathrm{pH}$ value ranged from 7.82 as the lowest at the upstream to 7.95 as the highest at the downstream of the Lahumoko river, indicating an increasing trend towards downstream. Increased conductivity is associated with organic pollution (which might have caused high levels of nitrogen) and high pH values (Silva et al. 2012; Gimenez et al. 2014). The pH at aquatic ecosystem is important because it is related to 
biological productivity. Although the value of the tolerance of each individual varies, in general, the $\mathrm{pH}$ value ranging from 6.5 to 8.5 is usually a good indicator of water quality (Dutta et al. 2014). River flow velocities and discharges are strongly influenced by land use activities by which downstream in flat areas is characterized by agricultural activities and settlements resulting in high surface flow (Mori et al. 2015; Ambarita et al. 2016). The human intervention on the Lahumoko Watershed in the form of agricultural land use and rural settlements have an effect on soil compaction, so it will cause changes in aquatic ecosystems, namely increasing river flow due to riverbank erosion, and changing physicochemical conditions in water (Almeida et al. 2009; Doll et al. 2016; dos Reis et al. 2017).

\section{Measurement of ecological indicators of river water quality}

Based on the FBI value according to Hilsenhoff (1998), the predicted water quality at different sampling stations ranged from fair, indicating fairly substantial pollution likely of organic pollution degree at three stations (LM1, LM2 and LM3) to fairly poor at two stations (LM4 and LM5), indicating substantial pollution of organic pollution (Dutta et al. 2014; Moran 2016; Krisanti et al. 2017). In the downstream river area where there was a settlement there were macroinvertebrates as an indicator of high levels of pollution with an FBI value> 6 (Bourassa et al. 2017).

The Shannon diversity index $\left(\mathrm{H}^{\prime}\right)$, richness index $(\mathrm{C})$, and evenness index (E) are widely used to predict aquatic environmental conditions based on the biological components (Maneechan and Prommi 2015; Patang et al. 2018). The higher Shannon diversity index means, the better the quality of water: the value of $\mathrm{H}^{\prime}$ smaller than one indicates high water pollution, between one and three moderate pollutions and greater than four no pollution (Wilhm and Dorris 1968). The Shannon diversity index $\left(\mathrm{H}^{\prime}\right)$ values at all stations on the Lahumoko River were above one, so the water at all the observation stations was moderately polluted (Barman and Gupta 2016).

In this study, the diversity in the upstream and downstream areas did not show differences, but there was a tendency for the upstream to increase the diversity. This was supported by dominance and evenness index, which showed that the diversity value at the upstream area was higher (Magurran 2004; Chirwa and Chilima 2017). All stations of Lahumoko rivers had dominance index value with low to moderate richness, but the evenness of species was high, so they had moderate diversity according to $\mathrm{H}^{\prime}$ index (Magurran 2004; Hepp et al. 2013).

\section{Correlation between physicochemical parameters and ecological indicators of water quality based on macroinvertebrates}

The abundance of aquatic macroinvertebrates observed was influenced by sampling locations (upstream, middle and downstream) including natural conditions (forest) and the presence of anthropogenic activities (development of agriculture and rural settlements). There were correlations between environmental factors and species abundance and ecological indicators of river water quality index (Table 5).
The velocity and discharge had significantly negative correlation with total individual and family abundance especially Goeridae, and Thiaridae (Lewin et al. 2015; Jun et al. 2016; Mathers et al. 2017), but significantly positive correlation with family Messovelidae that tolerates a high velocity (Wang et al. 2016; Nguyen et al. 2018). Stream velocity and flow discharge are the most important variable which influences diversity, community composition and spatial pattern abundance of macroinvertebrates (Rawi et al. 2013; Nguyen et al. 2018). Water temperature was significantly negatively correlated with family abundance especially Atyidae. Many studies reported about the removal of riparian vegetation because of the increasing use of agricultural land increased temperature and light level (Rutherford et al. 2004; Theodoropoulos et al. 2015), increasing runoff water which had a negative impact on macroinvertebrates communities. The $\mathrm{pH}$ had significantly negative correlation with Goeridae family and significantly positive correlation with the family biotic and evenness indexes. Similarly, dissolved oxygen had a significantly positive correlation with the family Heptagenidae (Jonsson et al. 2017). Factors that can result in variations in DO levels may include reduced oxygen produced from excessive amount of nutrients that usually limits plant growth. Low DO level is sometimes associated with agriculture and rural settlement land use. The $\mathrm{pH}$ values were within the acceptable range and dissolved oxygen was above the threshold. The effects of forest and disturbed area on the $\mathrm{pH}$ and dissolved oxygen are significant at relatively large riparian widths (Zhang et al. 2013; Jun et al. 2016). Meanwhile, TDS with evenness index were correlated significantly positively. Furthermore, conductivity was significantly negatively correlated with the family Heptagenidae and index of biotic family (Theodoropoulos et al. 2014).

The CCA ordination analysis showed that variation in aquatic macroinvertebrates families was related to environmental parameters, diversity indexes, and station locations (be analyzed in Figure 4). The significant positive correlations were observed between dissolved oxygen, dominant families (Heptageniidae, Goeridae, Atyidae, Agridae, Thiaridae, Amphipterygidae, Cordullidae, and Tipulidae), biodiversity parameters (total individuals, H'Max, and R'Margalef) and station locations (LM1, LM2, and LM3). Dissolved oxygen plays a very important role in the survival of aquatic macroinvertebrates because aquatic organisms use oxygen in the process of respiration (Maneechan and Prommi 2015; Prommi and Payakka 2015; Shafie et al. 2017). The high amount of dissolved oxygen in the upstream area was caused by the dominant forest cover (Zhang et al. 2013; Ambarita et al. 2016). The macroinvertebrates taxa recorded in this study, Decapods were the most ubiquitous and abundant group in all sampling stations, followed by Gastropoda, Ephemeroptera and Trichoptera, and Odonata. Generally, the Ephemeroptera, Trichoptera and Odonata groups prefer habitats that have a lot of water vegetation especially in the upstream area (Arimoro et al. 2015). Overall the observation stations, family Thiaridae of Gastropods Order, and Atydae and family Parathepusidae of Decapoda Orde 
were the most frequently found at all stations since that family posses high tolerance to pollution (Bouchard 2004). The abundance of family Thiaridae at all observation stations indicated that the condition of the waters in all stations contained pollutants from organic materials because these organisms were macroinvertebrates groups that are resistant to pollutants.

According to the results of CCA, several small macroinvertebrates taxa (Parathepusidae, Palemonidae, Physidae, Mesovellidae, and Dytiscidae) had significantly negative correlations with several physicochemical parameters (velocity, discharge, $\mathrm{pH}$, temperature, TDS, and conductivity), and diversity indexes (FBI, Shannon and J'Evenness) and the location of observation stations in the middle and downstream areas of the watershed (LM4 and LM5). The study conducted by Olomukoro and Azubuike (2009) reported the abundance of mollusks (snails) that are commonly associated with high $\mathrm{pH}$ levels, and a slight decrease in acidity and increased alkalinity can determine the changes in the abundance of mollusks. The low abundance of macroinvertebrates taxa in agricultural and settlements areas were caused by the high of velocity and peak discharge due to reduced forest land cover. Forest reduction was closely related to rising water temperature. The runoff carrying sediments due to soil erosion causes increased TDS and water Conductivity (Wang et al. 2016). So, the changes of environmental parameters in the middle and downstream areas of the watershed due to agricultural activities and settlements could cause a decrease in abundance and the number of water macroinvertebrates. Sampling sites with low richness and density macroinvertebrates communities were associated with conductivity and non-forest areas. These variables related to activities in anthropogenic regions have more scattered sources of organic and inorganic material, especially water bodies without vegetative protection, resulted in higher conductivity (Johnson et al. 2012; Rezende et al. 2014).

Species richness, diversity and evenness indices at the various sampling stations appear to reflect water quality conditions at each location. High species diversity at LM1, LM2, and LM3 were associated with less polluted conditions, while lower biodiversity at LM4 and LM5 signified environmental stress due to gradually increasing human influence on water quality conditions in these locations. The relative abundance of Ephemeroptera and Trichoptera taxa was greater at LM1, LM2, and LM3, which showed better water conditions than in LM4 and LM5. At the upstream of the river, there was high environmental heterogeneity that supported fauna life, which differentiated it from the middle and downstream areas (Bae et al. 2016). Most macroinvertebrates taxa from Ephemoptera and Trichoptera were negatively correlated with gradient streams, positively correlated with altitude. Several studies showed that these taxa have a negative correlation with river flow altitude (Lewin et al. 2015).

Each station had dominant macroinvertebrates, depending on sensitivity to the physical and chemical conditions, so it can be seen whether the biota is tolerant of poor water quality or not (Ligeiro et al. 2013). Hemiptera and Coleoptera are natural predatory organisms that have a high tolerance to environmental conditions. In this study, family Mesovelidae of Hemiptera was positively correlated with the flow velocity and DO, especially in the middle and downstream areas which serve as an indication that the water quality in the area was medium to good. These organisms also indicate that the area has been occupied, so the presence and density of these species determine the health of aquatic ecosystems (Barman and Gupta 2016).

In conclusion, land use changes in the Lahumoko Watersheds had direct impacts on water quality parameters in rivers, in upstream, middle stream and downstream of the watershed as a result of anthropogenic activities associated with land use types. Forest land use resulted in the best water quality, so agroforestry system should be practiced in the agricultural and settlement areas to improve the currently poor water quality due to human activities.

\section{ACKNOWLEDGEMENTS}

This article is part of the first author's dissertation and was presented at the International Conference on Biodiversity in Pontianak on 8-9 October 2016. The authors express their deep gratitude for those helping in conducting this research.

\section{REFERENCES}

Aazami J, Sari, AE, Abdoli A, Sohrabi H, Van den Brink PJ. 2015. Assessment of Ecological Quality of the Tajan River in Iran Using a Multimetric Macroinvertebrates Index and Species Traits. Environ Manag 56 (1): 260-269.

Almeida EF, Oliveira RB, Mugnai R, Nessimian JL, Baptista DF. 2009. Effects of Small Dams on the Benthic Community of Streams in an Atlantic Forest Area of Southeastern Brazil. Int Rev Hydrobiol 94: 179-193.

Ambarita MND, Everaert G, Forio MAE, Nguyen THT, Lock K, Musonge PLS, Suhareva N, Granda LD, Bennetsen E, Boets P, Goethals PLM. 2016. Generalized Linear Models to Identify Key Hydromorphological and Chemical Variables Determining the Occurrence of Macroinvertebrates in the Guayas River Basin (Ecuador). Water 8 (7): 297. DOI: 10.3390/W8070297.

Andrade TMB, Camargo PB, Silva DML, Piccolo MC, Vieira SA, Alves LF, Joly CA, Martinelli LA. 2011. Dynamics of Dissolved Forms of Carbon and Inorganic Nitrogen in Small Watersheds of the Coastal Atlantic Forest in Southeast Brazil. Water Air Soil Pollut: 393-408.

Arimoro FO, Odume ON, Uhunoma SI, Edegbene AO. 2015. Anthropogenic impact on water chemistry and benthic macroinvertebrates associated changes in a southern Nigeria stream. Environ Monit Assess 187: 14.

Azmi WA, Geok HA.2016. Aquatic Insect Communities in Relation With Water Quality Of Selected Tributaries of Tasik Kenyir Terengganu. J Sustain Sci Manag 11 (2): 11-20.

Bae MJ, Chun JH, Chon TS, Park YS. 2016. Spatio-Temporal Variability in Benthic Macroinvertebrates Communities in Headwater Streams in South Korea. Water 8 (3): 99. DOI: 10.3390/w8030099.

Barman B, Gupta S. 2016. Assemblage of Coleoptera and Hemiptera community in a stream of Chakrashila Wildlife Sanctuary in Assam. Trop Ecol 57 (2): 243-253. DOI: 10.1007/s00267-004-0211-x.

Bass D. 2003. A Comparison of Freshwater Macroinvertebrates Communities on Small Caribbean Islands. BioScience 53 (11): 10941100 .

Bouchard RW. 2004. Guide to aquatic invertebrates of the upper midwest: identification manual for students, citizen monitors, and aquatic resource professionals. Water Resources Research Center, University of Minnesota, St. Paul,MN. 
Bourassa AL, Fraser L, Beisner BE. 2017. Benthic macroinvertebrates and fish metacommunity structure in temperate urban streams. J Urban Ecol 3 (1): 1-14. DOI: 10.1093/jue/jux012.

Brooks KN, Ffolliott PF, Magner J A. 2013. Hydrology and the Management of Watersheds, 4th ed., A John Wiley \& Sons, Inc., New Jersey. ISBN: 9780470963050.

Chen J, Lu J. 2014. Effects of Land Use, Topography and SocioEconomic Factors on River Water Quality in a Mountainous Watershed with Intensive Agricultural Production in East China. PLoS One 9 (8): e102714. DOI: 10.1371/journal.pone.0102714.

Cheng P, Meng F, Wang Y, Zhang L, Yang Q, Jiang M. 2018. Impacts of Land Use Patterns on Water Quality in a Trans-Boundary River Basin in Northeast China Based on Eco-Functional Regionalization. Int $\mathbf{J}$ Environ Res Publ Health 15 (9): 1872.

Chirwa ER, Chilima L. 2017. Use of Benthic Macroinvertebrates Indices as Bioindicators of Ecosystem Health for the Detection of Degraded Landscapes in Malawi. Intl J Agric For Fish 5 (6): 128-134.

Copatti JBCE, Ross M, Copatti BR, Seibel LF. 2013. Bioassessment using benthic macroinvertebrates of the water quality in the Tigreiro river. Maringa 35 (4): 521-529. DOI: 10.4025/actascibiolsci.v35i4.18934.

Dacayana CML, Hingco JT, Del Socorro MML. 2013. Benthic macroinvertebrates assemblage in Bulod River, Lanao del Norte, Philippines. J Multidisciplinary Stud 2 (1): 28-41. DOI: 10.7828/jmds.v2i1.398

Di Sabatino A, Cristiano G, Pinna M, Lombardo P, Miccoli FP, Marini G, Vignini P, Cicolani B. 2014. Structure, functional organization and biological traits of macroinvertebrates assemblages from leaf-bags and benthic samples in a third-order stream of Central Apennines (Italy). Ecol Indicat 46: 84-91.

Doll B, Jennings G, Spooner J, Penrose D, Usset J, Blackwell J, Fernandez M. 2016. Can Rapid Assessments Predict the Biotic Condition of Restored Streams? Water 8: 143. DOI: 10.3390/w8040143.

dos Reis FD, Salazar AE, Machado MMD, Couceiro SRM, Morais PBD 2017. Measurement of the ecological integrity of cerrado streams using biological metrics and the index of habitat integrity. Insects 8 (1): 10 .

Dutta B, Baruah D, Biswas SP. 2014. Biomonitoring of benthic macroinvertebrates of the tail race of Dikhow River, Assam, India. Int J Fish Aquat Stud 1 (6): 72-81.

Edward JB, Adewumi AA, Idowu EO, Oso JA, Adeoba EA, Olofintoye LK. 2015. Pre-impoundment Macroinvertebrates Composition of Elemi River, Ado-Ekiti, Ekiti State, Nigeria. Int J Environ Monit Anal 3 (6): 425-434. DOI: 10.11648/j.ijema.20150306.17.

Elias JD, Ijumba JN, Mgaya YD, Mamboya FA. 2014. Study on Freshwater Macroinvertebrates of Some Tanzanian Rivers as a Basis for Developing Biomonitoring Index for Assessing Pollution in Tropical African Regions. J Ecosyst. DOI: 10.1155/2014/985389.

Fierro P, Bertran C, Mercado M, Pena Cortes F, Tapia J, Hauenstein E, Caputo L, Vargas Chacoff L. 2015. Landscape composition as a determinant of diversity and functional feeding groups of aquatic macroinvertebrates in southern rivers of the Araucania, Chile. Latin Am J Aquat Res 43 (1): 186-200.

Flotemersch JE, Leibowitz SG, Hill RA, Stoddard JL, Thoms MC, Tharme RE. 2016. A watershed integrity definition and assessment approach to support strategic management of watersheds. River Res Appl 32: 1654-1671.

Fonnesu A, Pinna M, Basset A, 2004. Spatial and temporal variations of detritus breakdown rates in the river Flumendosa basin (Sardinia, Italy). Intl Rev Hydrobiol 89 (5/6): 443-452.

Foto MS, Tchakonte S, Ajeagah GA, Zebaze TSH, Bilong BCF, Njine T. 2013. Water quality assessment using benthic macroinvertebrates in a periurban stream (Cameroon). Intl J Biotechnol 2 (5): 91-104.

Fu L, Jiang Y, Ding J, Liu Q, Peng QZ, Kang MY. 2016. Impacts of land use and environmental factors on macroinvertebrates functional feeding groups in the Dongjiang River basin, Southeast China. J Freshw Ecol 31 (1): 21-35

Gerth WJ, Li J, Giannico GR. 2017. Agricultural land use and macroinvertebrates assemblages in lowland temporary streams of the Willamette Valley, Oregon, USA. Agric Ecosyst Environ 236: 154165. DOI: 10.1016/j.agee.2016.11.010.

Gimenez BCG, Lansac-Tôhaa FA, Higutia J. 2015. Effect of land use on the composition, diversity and abundance of insects drifting in neotropical streams. Braz J Biol 75 (4): S52-S59.

Hamel P, Riveros-Iregui D, Ballari D, Browning T, Célleri R, Chandler D, Chun KP, Destouni G, Jacobs S, Jasechko S, Johnson M,
Krishnaswamy J, Poca M, Pompeu PV, Rocha H. 2017. Watershed services in the humid tropics: Opportunities from recent advances in ecohydrology. Ecohydrology 11: e1921. DOI: 10.1002/eco.1921.

Harikumar PSP, Deepak R, Sabitha AR. 2014. Water Quality Assessment of Valapattanam River Basin in Kerala, India, using MacroInvertebrates as Biological Indicators. Open Environ Biol Monit J 6: $1-9$

Heino J, Ilmonen J, Paasivirta L. 2014. Continuous variation of macroinvertebrates communities along environmental gradients in northern streams. Boreal Environ Res 19: 21-38.

Hepp LU, Restello RM, Milesi SV, Biasi C, Molozzi J. 2013. Distribution of aquatic insects in urban headwaters streams. Acta Limnol Brasiliensia 25 (1): 1-9.

Hilsenhoff WL. 1998. A modification of the biotic index of organic stream pollution to remedy problems and permit its use throughout the year. Great Lakes Entomol 31: 1-12.

Jiang X, Xiong J, Xie Z, Chen Y. 2011. Longitudinal patterns of macroinvertebrates functional feeding groups in a Chinese river system: A test for river continuum concept (RCC). Quat Int 244 (2): 289-295.

Johnson RC, Smith DP, McMichael CE. 2012. Scale Dependence in Relating Land Use/Cover to Stream Macroinvertebrates Communities in the Central Appalachian Mountains, USA. Sci Rem Sens 49 (1): 53-70.

Jonsson M, Burrows RM, Lidman J, Faltstrom E, Laudon H, Sponseller RA. 2017. Land use influences macroinvertebrates community composition in boreal headwaters through altered stream conditions. Ambio 46: 311-323.

Jun YC, Kim NY, Kim SH, Park YS, Kong DS, Hwang SJ. 2016. Spatial Distribution of Benthic Macroinvertebrates Assemblages in Relation to Environmental Variables in Korean Nationwide Streams. Water 8 (1): 27

Khatri N, Tyagi S. 2015. Influences of natural and anthropogenic factors on surface and groundwater quality in rural and urban areas. Front Life Sci 8 (1): 23-39. DOI: 10.1080/21553769.2014.933716.

Kim DH, Chon TS, Kwak GS, Lee SB, Park YS. 2016. Effects of land use types on community structure patterns of benthic macroinvertebrates in streams of urban areas in the south of the Korea Peninsula. Water 8 (5): 187.

Kripa PK, Prasanth KM, Sreejesh KK, Thomas TP. 2013. Aquatic macroinvertebrates as bioindicators of stream water quality a case study in Koratty, Kerala, India. Res J Recent Sci 2: 217-222.

Krisanti M, Wardiatno Y, Anzani YM, 2017. Assessing the ecological status of the Cisadane Rivers headwaters using benthic macroinvertebrates. IOP Conf. Series: Earth and Environmental Science 54 (2017): 012023. DOI: 10.1088/1755-1315/54/1/012023

Legendre P, Legendre L. 1998. Numerical Ecology. 2nd ed. Elsevier Science B.V., Amsterdam.

Lewin I, Szoszkiewicz K, Jusik S, Lawniczak AE. 2015. Influence of selected environmental factors on macroinvertebrates in mountain streams. Open Life Sci 10 (1): 99-111. DOI: 10.1515/biol-201500081.

Ligeiro R, Hughes RM, Kaufmann PR, Macedo DR, Firmiano, KR, Ferreira WR, Oliveira D, Melo AS, Callisto M. 2013. Defining quantitative steam disturbance gradients and the additive role of habitat variation to explain macroinvertebrates taxa richness. Ecol Indicators 25: 45-57. DOI: 10.1016/j.ecolind.2012.09.004.

Magurran AE. 2004. Measuring biological diversity, 2nd ed. Blackwell Science Ltd, Oxford, UK

Maneechan W, Prommi TO, 2015 Diversity and distribution of aquatic insects in stream of the Mae Klong watershed, western Thailand. Psyche 2015 (2): 1-7

Martin TE, Nightingale J, Baddams J, Monkhouse J, Kaban A Sastranegara H, Mulyani Y, Blackburn GA, Simcox W. 2017. Variability in the effectiveness of two ornithological survey methods between tropical forest ecosystems. PLoS One 12 (1). DOI: 10.1371/journal.pone.0169786.

Masese FO, Kitaka N, Kipkemboi J, Gettel GM, Irvine K, McClain ME. 2014. Macroinvertebrates functional feeding groups in Kenyan Highland Streams: Evidence for a diverse shredder guild. Freshw Sci 33 (2): 435-445

Mathers KL, Hill MJ, Wood PJ. 2017. Benthic and hyporheic macroinvertebrates distribution within the heads and tails of riffles during baseflow conditions. Hydrobiologia 794 (1): 17-30. DOI: 10.1007/s10750-017-3092-8. 
Minshall GW, Shafii B, Price WJ, Holderman C, Anders PJ, Lester G, Barrett P. 2014. Effects of nutrient replacement on benthic macroinvertebrates in an ultraoligotrophic reach of the Kootenai River, 2003-2010. Freshw Sci 33 (4): 1009-1023.

Mophin-Kani K, Murugesan, 2014. Assessment of river water quality using macroinvertebrates organisms as pollution indicators of Tamirabarani River Basin, Tamil Nadu, India. Intl J Environ Prot 4 (1): $1-14$.

Moran J. 2016. Application of Family Biotic Index in Assessment of two Rivers Affected by Oil Pollution in Assam, India. Intl Res J Environ Sci 5 (11): 35-40,

Mori GB, de Paula FR, de Barros Ferraz SF, Camargo AFM, Martinelli LA. 2015. Influence of landscape properties on stream water quality in agricultural catchments in Southeastern Brazil. Ann Limnol Intl J Lim 51: 11-21.

Niyogi DK, Simon KS, Townsend CR. 2004. Land use and stream ecosystem functioning: nutrient uptake in streams that contrast in agricultural development. Arch Hydrobiol160: 471-486.

Nguyen THT, Forio MAE, Boets P, Lock K, Ambarita MND, Suhareva N, Everaert G, Van der Heyden C, Dominguez-Granda LE, Hoang THT, Goethals P. 2018. Threshold Responses of Macroinvertebrates Communities to Stream Velocity in Relation to Hydropower Dam: A Case Study from The Guayas River Basin (Ecuador). Water 10: 1195.

Ojija F, Kavishe R. 2016. A Preliminary Study on Abundance and Diversity of Aquatic Macro Invertebrates of Nzovwe Stream, in Mbeya, Tanzania. Intl J Life Sci Res 4 (1): 29-38.

Ojija F, Laizer H. 2016. Macroinvertebrates as bioindicators of water quality in Nzovwe Stream, in Mbeya, Tanzania. Intl J Sci Technol Res 5 (6): 211-222.

Olomukoro JO, Azubuike CN. 2009. Heavy metals and macroinvertebrates communities in bottom sediment of Ekpan Creek, Warri, Nigeria. J Biol Sci 2 (1): 1-82.

Olomukoro JO, Dirisu AR. 2014. Macroinvertebrates Community and Pollution Tolerance Index in Edion and Omodo Rivers in Derived Savannah Wetlands in Southern Nigeria. Jordan J Biol Sci 7 (1): 1924.

Patang F, Soegianto A, Hariyanto S. 2018. Benthic macroinvertebrates diversity as bioindicator of water quality of some rivers in East Kalimantan, Indonesia. Intl J Ecol 2018: 5129421. DOI: $10.1155 / 2018 / 5129421$

Patrick MS, Marie TMJ, Nadine ML. 2015. Benthic macroinvertebrates as indicators of water quality: a case-study of urban Funa Stream (in Kinshasa, Democratic Republic of Congo). Open J Water Pollut Treat 2 (1): 8-24. DOI: 10.15764/WPT.2015.01002.

Patterson G, Tosh DG, Martin TE, Adams N, Cropper O, Mustari AH 2017. Lowland rainforest bat communities of Buton Island, Southeast Sulawesi, including new regional records. Raffles Bull Zool 65: 373 385.

Pinna M, Sangiorgio F, Fonnesu A, Basset A. 2003. Spatial analysis of plant detritus processing in a Mediterranean River type: the case of the River Tirso Basin (Sardinia, Italy). J Environ Sci 15 (2): 227-240.

Pinna M, Marini G, Cristiano G, Mazzotta L, Vignini P, Cicolani B, Di Sabatino A. 2016. Influence of aperiodic summer droughts on leaf litter breakdown and macroinvertebrates assemblages: testing the drying memory in a Central Apennines River (Aterno River, Italy). Hydrobiologia 782: 111-126.

Powling A, Phillips A, Pritchett R, Segar ST, Wheeler R, Mardiastuti A. 2015. The Vegetation Of Lambusango Forest, Buton, Indonesia. $\begin{array}{llll}\text { Reinwardtia } & 14 & (2): & 265-286 .\end{array}$ 10.1017/CBO9781107415324.004.

Prommi T, Payakka A. 2015 Aquatic insect biodiversity and water quality parameters of streams in Northern Thailand. Sains Malaysiana 44 (5): 707-717.

Pullanikkatil D, Palamuleni LG, Ruhiiga TM. 2015. Impact of land use on water quality in the Likangala catchment, southern Malawi. Afr J Aquat Sci 40 (3): 277-286. DOI: 10.2989/16085914.2015.1077777.

Rawi CSM, Al-Shami SA, Madrus MR, Ahmad AH. 2013. Biological and ecological diversity of aquatic macroinvertebrates in response to hydrological and physicochemical parameters in tropical forest streams of Gunung Tebu, Malaysia: Implications for ecohydrological assessment. Ecohydrology 7: 496-507.

Rezende RS, Santos AM, Oliveira CH, Goncalves JF. 2014. Effects of spatial and environmental factors on benthic a macroinvertebrates community. Zoologia 31 (5): 426-434. DOI: 10.1590/S198446702014005000001 .
Rosenberg DM, Resh VH. 1993. Introduction to Freshwater Biomonitoring and Benthic Macroinvertebrates. In: Rosenberg DM, Resh VH (eds) Freshwater Biomonitoring and Benthic Macroinvertebrates, Chapman/Hall, New York.

Rutherford JC, Marsh NA, Davies PM, Bunn SE. 2004. Effects of patchy shade on stream water temperatures; how quickly do small streams heat and cool? Mar Freshw Res 55: 737-748.

Sangiorgio F, Pinna M, Basset A. 2004. Inter-and intra-habitat variability of plant detritus decomposition in a transitional environment (Lake Alimini, Adriatic Sea). Chem Ecol 20 (1): S353-S366.

Santhosh S, Mohan K, Dhanesh C, Sobha NR, Akolker VP. 2014. Biomonitoring status and contribution to the knowledge of benthic macroinvertebrates for river Meenachil, Southern Kerala, India: A First case approach. Intl J Adv Res Biol Sci 1 (6): 218-225.

Saviour MN. 2012. Environmental impact of soil and sand mining: a review. Int J Sci Environ Technol 1 (3): 125-134.

Selvanayagam M, Abril R. 2016. Use of benthic macro-invertebrates as a biological indicator in assessing water quality of River Puyo, Puyo, Pastaza, Ecuador. Am J Life Sci 4 (1): 1-12.

Shafie MSI, Wong ABH, Harun S, Fikri AH 2017. Land use influence on the aquatic insect communities on tropical forest streams of Liwagu River, Sabah, Malaysia. AACL Bioflux 10 (2): 341-352.

Shannon CE. 1948. A mathematical theory of communications. Bell Syst Tech J 27: 379-423; 623-656

Sharifinia M, Namin JI, Mahmoudifard A, Ramezanpour Z, Gholami K. 2016. Benthic diatom and macroinvertebrates assemblages, a key for evaluation of river health and pollution in the Shahrood River, Iran. Limnology 17 (1): 95-109.

Shokri M, Rossaro B, Rahmani H. 2014. Response of macroinvertebrates communities to anthropogenic pressures in Tajan River (Iran). Biologia 69 (10): 1395-1409.

Silva DML, Camargo PB, Mcdowell WH, Vieira I, Salomão MSMB, Martinelli LA. 2012. Influence of land use changes on water chemistry in streams in the State of São Paulo, southeast Brazil. Anais da Academia Brasileira de Ciências 84 (4): 919-930.

Sikumbang N, Sanyoto P, Supandjono RJB, Gafoer S. 1995. Geological Map of the Buton Sheet, Southeast Sulawesi. Geological Research and Development Centre. Bandung, Indonesia. [Indonesian]

Smith RB, Silver EA. 1991.Geology of a Miocene collision complex, Buton, Eastern Indonesia. GSA Bull 103 (5): 660-678.

Szczerkowska-Majchrzak E, Grzybkowska M. 2015. Effects of hydrological disturbance of different magnitude on riverine habitats and benthic invertebrates. Polish J Ecol 63 (1): DOI: 10.3161/15052249PJE2015.63.1.012.

Tesfaye G, Assefa A, Kidane D. 2017. Runoff, sediment load and land use/cover change relationship: the case of Maybar sub-watershed, South Wollo, Ethiopia. Int J River Basin Manag 15 (1): 89-101.

Thampy JPS, Raja M, Thambiratnam S, Arunchalam. 2013. Application of rapid bioassessment in selected stream of the Western Ghats using benthic macroinvertebrates. Intl J Environ Biol 3 (4): 173-179.

Theodoropoulos C, Aspridis D, Iliopoulou-Georgudaki J. 2015. The influence of land use on freshwater macroinvertebrates in a regulated and temporary Mediterranean river network. Hydrobiologia (2015) 751: 201-213

Troussellier M, Legendre P. 1981. A functional evenness index for microbial ecology. Microb Ecol 7 (4): 283-296.

Uhlenbrook S, Roser S, Tilch N. 2004. Hydrological process representation at the mesoscale: The potential of a distributed, conceptual catchment model. J Hydrol 291 (3-4): 278-296.

Vannote RL, Minshall GW, Cummins KW, Sedell JR, Cushing CE. 1980. The river continuum concept. Can J Fish Aquat Sci 37 (1): 130-137.

Wang H, Chen Y, Liu Z, Zhu D. 2016. Effects of the "Run-of-River" hydro scheme on macroinvertebrates communities and habitat conditions in a mountain river of Northeastern China. Water 8 (1): 116 .

Whitten T, Mustafa M, Henderson GS. 2002. The Ecology of Sulawesi. 2nd ed. Gadjah Mada University Press, Yogyakarta.

Wilhm JL, Dorris TC, 1968. Biological parameters for water quality criteria. J Biosci 18: 477-481.

Yazdian H, Jaafarzadeh N, Zahraie B. Relationship between benthic macroinvertebrates bio-indices and physicochemical parameters of water: a tool for water resources managers. J Environ Health Sci Eng 12: 30 .

Young SS, Yang HN, Huang DJ, Liu SM, Huang YH, Chiang CT, Liu JW. 2014. Using benthic macroinvertebrates and fish communities as bioindicators of the tanshui river basin around the Greater Taipei 
Area-Multivariate analysis of spatial variation related to levels of water pollution. Intl J Environ Res Public Health 11 (7): 7116-7143.

Zaiha AN, Mohd Ismid MS, Salmiati, Shahrul Azri MS. 2015. Effects of logging activities on ecological water quality indicators in the Berasau River, Johor, Malaysia. Environ Monit Assess 187: 493 DOI: $10.1007 / \mathrm{s} 10661-015-4715-\mathrm{z}$.
Zhang Y, Zhao R, Kong W, Geng S, Bentsen CN, Qu X. 2013. Relationships between macroinvertebrates communities and land use types within different riparian widths in three headwater streams of Taizi River, China. J Freshw Ecol 28 (3): 307-328. 